\title{
THE INFLUENCE OF STRUCTURAL VARIATIONS ON WOOL FABRICS AIR PERMEABILITY
}

Sonja Jordeva ${ }^{1}$, Elena Tomovska², Koleta Zafirova2 ${ }^{2^{*}}$

${ }^{1}$ Faculty of Technology, University "Goce Delcev", Stip, Macedonia

2Faculty of Technology and Metallurgy, University "Ss Cyril and Methodius", Skopje, Macedonia (PROFESSIONAL PAPER)
UDC $677.074 .31: 677.017 .6$

Woven fabrics are materials of a sophisticated structure. Basic structural parameters, the raw material, linear density of warp and weft yarn, number of yarn twist, warp and weft density, warp and weft crimp, as well as weave contribute to the obtained properties of the fabric. Certain basic parameters of the fabric can be controlled directly either during the preparatory processes or during the weaving process itself. There are some important structural parameters, however, for which no direct quantitative controls exist. Since all structural parameters are closely interdependent, the lack of direct control results in an imperfect control of the fabric structure.

The subject of the investigation was how small variations in semi-worsted wool fabric constructional parameters influence the air permeability, and to which extent they can be controlled in the design process and weaving of fabrics.

The experiment showed that yarn count, warp and weft density and warp and weft crimp are highly interrelated, leading to small variations in the fixed sett. The statistical significance of small variations in the groups of fabrics was confirmed by the analysis of variance. The analysis confirmed that there were no differences in mass, although all other structural parameters differed. Additionally, a post-hoc Bonferroni test showed that the structural parameters of the group of fabrics, which has a practically balanced structure, are always different to those of groups g2 and g3. Fabric alternations done on the same warp, in such a manner to achieve the same mass per square meter, showed that the change in weft yarn count and weft density influenced the fabric structure as a result of the crimp interchange. However, there was not a statistically significant difference among the three groups of fabrics when tested for air permeability.

\section{Introduction}

Woven fabrics are materials of a sophisticated structure. Basic structural parameters, the raw material, linear density of warp and weft yarn, number of yarn twist, warp and weft density, warp and weft crimp, as well as weave contribute to the obtained properties of the fabric. Certain basic parameters of the fabric can be controlled directly either during the preparatory processes or during the weaving process itself. There are some important structural parameters, however, for which no direct quantitative controls exist. Since all structural parameters are closely interdependent, the lack of direct control results in an imperfect control of the fabric structure. Furthermore, there are certain functions of the loom which, at first sight, do not seem to affect the fabric structure. However, closer examination shows important effects. Lastly, even some direct and simple controls of the fabric structure operate in a more complicated manner of what is apparent at first sight. It was noticed that the properties of fabrics with the same setting parameters, but weaved on various looms or in various companies were different [1]. Also, the implemented tension on warp and weft, even on the same loom, can differ during the weaving process, resulting in variation in the fabric structure. When the structure of the fabric is different, the properties are different, too. The investigations showed that the woven fabric structure influences air permeability, strength, elongation, etc. [2-4]. A number of authors [58] have dealt with the possibility to predict the value of the air permeability of fabrics based on their structural parameters. In some applications, woven fabrics are used as filters or protective barriers whose function is to prevent the penetration into the human body of various micro particles or microorganisms. The elements of the structure which decide whether a woven fabric is capable of performing such a function are the inter-yarn pores, dependent on the weave and structural parameters of

\footnotetext{
*Author address: Koleta Zafirova, Faculty of Technology and Metallurgy, Rudjer Bošković 16, Skopje, Macedonia

E-mail: etomovska@tmf.ukim.edu.mk

The manuscript received: July, 18, 2016.

Paper accepted: August, 18, 2016.
} 
the fabric. These factors need to be pre-determined in the designing phase and realized in the weaving process $[6,7,8]$. The structure of a fabric is usually characterized by its porosity $[8,9,10,11]$. The total porosity of woven fabrics usually comprises of two types of porosity, i.e., the micro porosity (or intra-yarn porosity) caused by the void spaces between fibers in yarns, and the macro porosity (or inter-yarn porosity) caused by the void spaces between yarns. Constructional parameters such as linear density of yarns, a sett of yarns, a type of weave and the production technology used can be combined in various ways. The structure of the fabrics made can be very similar or very different, but the permeability of two fabrics which have an apparently very similar structure may be very different. The fabric air permeability is mainly determined by its inter-yarn pores (their size, shape, texture, mutual arrangement, etc.). This issue has already been described in several papers. The air permeability of the fabric is also highly influenced by its type of weave. Any weave can be created using the four basic inter-yarn pores described by Backer [1]. Some authors, e.g. $[9,10,11]$ describe the effect of the number and shape of these four pore cells in the air permeability of the fabric.
The aim of this paper is to observe how small variations in semi-worsted wool fabric constructional parameters influence the air permeability, and to which extent they can be controlled in the design process and weaving of fabrics.

\section{Experimental}

\section{Sampling}

Sampling is a quite subtle operation when woven fabrics are concerned. As looms do not provide a direct quantitative control of warp and weft crimp it is rather hard to avoid small variations in the sample properties. The samples were woven on the same Sulzer projectile loom. The warp density (ends) was kept constant $\left(\mathrm{ge}=22 \mathrm{~cm}^{-1}\right)$, while three planned weft counts were used: $\mathrm{T}_{\mathrm{tp} 1}=21 \times 2 \mathrm{tex}, \mathrm{T}_{\mathrm{tp} 2}=25 \mathrm{x} 2 \mathrm{tex}$ and $\mathrm{T}_{\mathrm{tp} 3}=32 \mathrm{x} 2 \mathrm{tex}$. Moreover, for every weft count three different weft densities (picks) were used; consequently, nine samples with, to some extent, different constructional parameters were obtained. The weave used was twill 2/2.The investigation was performed on grey fabrics. The samples were coded as in Table 1.

Table 1. Samples codes

\begin{tabular}{|c|c|c|c|c|c|c|c|c|c|}
\hline Yarn (tex) & & $\mathrm{T}_{\mathrm{tp} 1}=21 \mathrm{X}$ & & & $\mathrm{T}_{\mathrm{tp} 2}=24 \mathrm{Y}$ & & & $T_{\mathrm{tp} 3}=32 \mathrm{x}$ & \\
\hline $\begin{array}{l}\text { Density }\left(\mathrm{cm}^{-1}\right) \\
\text { Fabric code }\end{array}$ & $\begin{array}{l}g_{p 1}=22 \\
g 11\end{array}$ & $\begin{array}{l}g_{p 2}=23 \\
g 12\end{array}$ & $\begin{array}{l}g_{\mathrm{p} 3}=24 \\
\mathrm{~g} 13\end{array}$ & $\begin{array}{l}\mathrm{g}_{\mathrm{p} 1}=19 \\
\mathrm{~g} 21\end{array}$ & $\begin{array}{l}\mathrm{g}_{\mathrm{p} 2}=20 \\
\mathrm{~g} 22\end{array}$ & $\begin{array}{l}g_{p 3}=21 \\
g 23\end{array}$ & $\begin{array}{l}g_{p 1}=17 \\
g 31\end{array}$ & $\begin{array}{l}g_{\mathrm{p} 2}=18 \\
\mathrm{~g} 32\end{array}$ & $\begin{array}{l}\mathrm{gp}_{\mathrm{p} 3}=19 \\
\mathrm{~g} 3\end{array}$ \\
\hline
\end{tabular}

The structural parameters for the samples design were chosen to provide the samples with as much as possible uniform mass per square meter, as the fabric mass is the primary parameter in fabrics merchandising.

Table 2. Yarn measurements

\begin{tabular}{lccc}
\hline Yarn & $\mathbf{T}_{\text {tp1 }}$ & $\mathbf{T}_{\text {tp2 }}$ & $\mathbf{T}_{\text {tp3 }}$ \\
\hline Yarn count (tex) & $21.2 \times 2$ & $25.2 \times 2$ & $31.2 \times 2$ \\
CV (\%) & 1.6 & 2.6 & 2.5 \\
Yarn twist $\left(\mathbf{m}^{-1}\right)$ & 611 & 502 & 494 \\
CV (\%) & 1.8 & 0.4 & 4.0 \\
\hline
\end{tabular}

\section{Results and disscusion}

Since air permeability is dependent on inter-yarn porosity, firstly the yarn parameters, i.e., yarn count and yarn twist were measured. The results are presented in Table 2. Standard tolerable variation of wool yarn count is $2-3 \%$. The most uniform yarn is $T_{t p 1}$, as opposed to $T_{t p 2}$ which has the highest variation. The yarn twist of $T_{t p 1}$ is

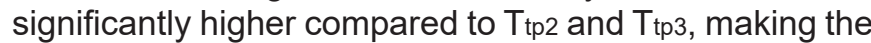
former less voluminous. The variation in the yarn twist differs with the three yarns, which also influences their air permeability.

Structural parameters and properties of the obtained fabric samples, warp and weft density, warp and weft crimp, mass per unit area, thickness and air permeability were tested with standard methods. The results are presented in Table 3.

During the sampling process, as yarn count was increased, the weft density was decreased in order to obtain the same mass per square meter for the samples. The obtained fabric mass was from 199.75 to $224.46 \mathrm{~g} / \mathrm{m}^{2}$, with the coefficient of variation $3.22 \%$. The standard tolerable variation in woven fabric mass is up to $5 \%$.

When fabrics were off the loom and relaxed from tensions, the fabric structural changes were analysed. Yarn count, warp and weft density and warp and weft crimp were highly interrelated leading to small variations in the fixed sett. The statistical significance of small variations in the groups of fabrics (g1, g2, g3) was confirmed by the analysis of variance (Table 4). The analysis confirmed that there were no differences in mass, although all other structural parameters differed. Additionally, a post-hoc Bonferroni test (Table4) was conducted. The post-hoc analysis showed that the structural parameters of the first group of fabrics, g1, which has a practically balanced structure, are always different from those of groups g2 and g3.

Firstly, the warp density was kept constant $\left(g e=22 \mathrm{~cm}^{-1}\right)$, but the introduction of the coarser weft yarn into the fabrics resulted in a decrease in warp density. 
The difference in the warp density is negligible with the variation coefficient of $0.7 \%$. The weft density, for every group of fabrics (g1, g2 and g3) was altered for one pick. The obtained values slightly differed from the fixed sett. The maximum difference of two wefts within the groups of fabrics (g1, g2, g3) showed the variation coefficient of $4.4 \%, 4.3 \%$ and $4.4 \%$ respectively.

Although the mass of the fabrics is kept at the same value, the changes in warp and weft crimp, as a result of altering the input parameters, are noticeable from fabric thickness values. The first group of fabrics, g1, showed close values of warp and weft crimp and consequently the lowest thickness. The second and third group of fabrics, g2 and g3, with the coarser weft yarn used, showed the increased difference between warp and weft crimp leading to higher thickness. The Pearson's correlation coefficient between the difference of warp and weft crimp and fabric thickness is 0.97 . Fabric alternations were done on the same warp, in such a manner to achieve the same mass per square meter and showed that the change in weft yarn count and weft density influenced the fabric structure as a result of crimp interchange in the fabrics. Warp crimp increased, while weft crimp decreased, leading to the increase in the fabric thickness.

Table 3. Samples structural parameters and properties

\begin{tabular}{|c|c|c|c|c|c|c|c|c|c|}
\hline \multirow{2}{*}{$\begin{array}{l}\text { Yarn count (tex) } \\
\text { Sample }\end{array}$} & \multicolumn{3}{|c|}{$T_{\mathrm{tp} 1}=21 \times 2$} & \multicolumn{3}{|c|}{$T_{\mathrm{tp} 2}=25 \times 2$} & \multicolumn{3}{|c|}{$T_{t p 3}=31,5 \times 2$} \\
\hline & g11 & g12 & g13 & g21 & g22 & g23 & g31 & g32 & g33 \\
\hline Weft density $\left(\mathrm{cm}^{-1}\right)$ & 22.00 & 23.50 & 24.50 & 19.40 & 20.60 & 21.60 & 17.40 & 18.40 & 19.40 \\
\hline Warp density $\left(\mathrm{cm}^{-1}\right)$ & 22.00 & 22.00 & 22.00 & 21.80 & 21.80 & 21.80 & 21.60 & 21.60 & 21.60 \\
\hline Warp crimp (\%) & 8.25 & 8.40 & 8.40 & 9.09 & 9.09 & 10.45 & 10.45 & 11.11 & 11.11 \\
\hline Weft crimp (\%) & 7.41 & 7.62 & 7.26 & 6.25 & 6.62 & 6.62 & 5.51 & 6.25 & 6.54 \\
\hline Crimp difference & 0.84 & 0.78 & 1.14 & 2.84 & 2.74 & 3.83 & 4.94 & 4.86 & 4.54 \\
\hline $\operatorname{Mass}\left(g / m^{2}\right)$ & 207.83 & 209.76 & 211.73 & 199.75 & 211.86 & 215.75 & 212.99 & 221.41 & 224.46 \\
\hline Thickness (mm) & 0.69 & 0.69 & 0.70 & 0.73 & 0.77 & 0.78 & 0.81 & 0.82 & 0.82 \\
\hline $\begin{array}{l}\text { Air permeability } \\
\left(\mathrm{m}^{3} / \mathrm{min} \cdot \mathrm{m}^{2}\right)\end{array}$ & 21.80 & 21.00 & 19.33 & 29.33 & 26.67 & 22.00 & 32.33 & 26.00 & 22.00 \\
\hline $\begin{array}{l}\text { Mass per volume } \\
\left(\mathrm{g} / \mathrm{cm}^{3}\right)\end{array}$ & 0.302 & 0.303 & 0.303 & 0.274 & 0.276 & 0.276 & 0.263 & 0.271 & 0.273 \\
\hline
\end{tabular}

Table 4. ANOVA of samples structural parameters

\begin{tabular}{lrrrrr}
\hline & \multicolumn{1}{c}{$\mathrm{g} 1$} & $\mathrm{~g} 2$ & $\mathrm{~g} 3$ & \multicolumn{1}{c}{$\mathrm{F}$} & $\mathrm{p}$ \\
\hline Weft density $\left(\mathrm{cm}^{-1}\right)$ & $23.33^{\mathrm{a}}$ & $20.53^{\mathrm{b}}$ & $18.40^{\mathrm{b}}$ & 14.5 & .005 \\
Warp crimp (\%) & $8.35^{\mathrm{a}}$ & $9.54^{\mathrm{b}}$ & $10.89^{\mathrm{b}}$ & 18.8 & .003 \\
Weft crimp (\%) & $7.43^{\mathrm{a}}$ & $6.49^{\mathrm{b}}$ & $6.10^{\mathrm{b}}$ & 11.6 & .009 \\
Crimp difference & $0.92^{\mathrm{a}}$ & $3.13^{\mathrm{b}}$ & $4.78^{\mathrm{c}}$ & 75.8 & .000 \\
Mass $\left(\mathrm{g} / \mathrm{m}^{2}\right)$ & $209.77^{\mathrm{a}}$ & 209.12 & 219.62 & 2.8 & .134 \\
Thickness $(\mathrm{mm})$ & $0.69^{\mathrm{a}}$ & $0.76^{\mathrm{b}}$ & $0.81^{\mathrm{c}}$ & 42.3 & .000 \\
$\rho(\mathrm{g} / \mathrm{cm} 3)$ & $0.30^{\mathrm{a}}$ & $0.27^{\mathrm{b}}$ & $0.26^{\mathrm{b}}$ & 100.8 & .000 \\
\hline a,b,c- different & & & & & \\
letters denote & & & & & \\
different groups in & & & & &
\end{tabular}

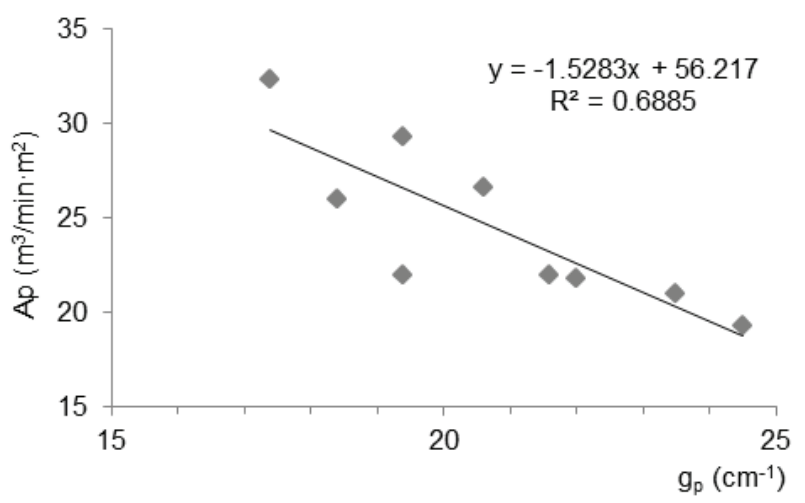

Figure 1. Regression curve of the relationship between weft density and air permeability

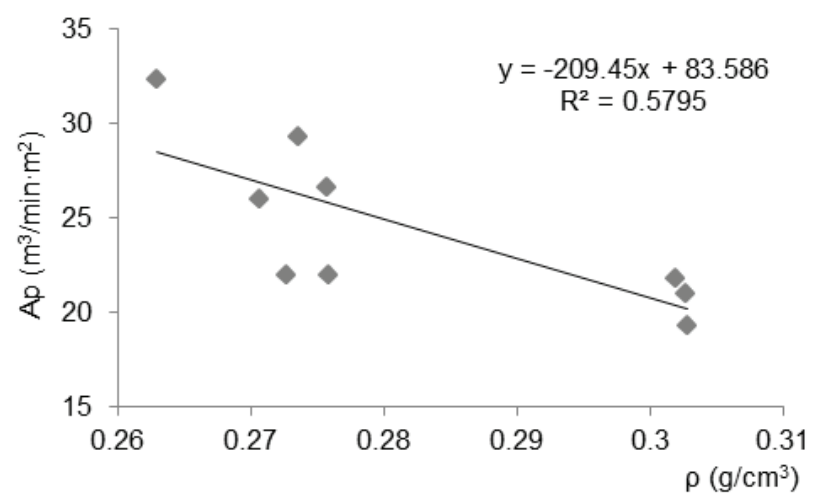

Figure 2. Regression curve of the relationship between mass per volume and air permeability 
Further on, the influence of small changes in the fabric density on air permeability was analysed. Air permeability showed high correlation coefficients with weft density and mass per volume (Figures 1 and 2). For the first group of fabrics g1, with the same yarn count for both systems of yarn, the coefficient of variation of air permeability is low $-4.9 \%$. The assumption is that a small difference of the weft density did not affect the air permeability. On the other hand, the introduction of the coarser weft yarn, declared as 50tex and 64tex and with around $100 t w i s t / m$ less, raised the value difference of air permeability. The coefficients of the variation of air permeability for the second (g2) and third (g3) group were $11.65 \%$ and $15.88 \%$, respectively. Doubtless, a higher value for air permeability is mostly caused by greater micro-porosity of implemented weft yarns than from the change of the weft density. Unlike mass and thickness which showed low correlation with air permeability, mass per volume, which is a close indicator of porosity, had a high Pearson's correlation coefficient (-0.76) with air permeability. However, there was not a statistically significant difference among the three groups of fabrics when tested for air permeability $(F=2.31, p=0.180)$. The constant obtained mass during the fabric production compensates for small structural differences in the fabric construction.

\section{Conclusions}

The experiment showed that yarn count, warp and weft density and warp and weft crimp are highly interrelated leading to small variations in the fixed sett. The statistical significance of small variations in the groups of fabrics (g1, g2, g3) was confirmed by the analysis of variance. The analysis confirmed that there were no differences in mass, although all other structural parameters differed. Additionally, a post-hoc Bonferroni test showed that the structural parameters of the first group of fabrics, $\mathrm{g} 1$, which has a practically balanced structure, are always different to those of groups g2 and g3.

Fabric alternations done on the same warp, in such a manner to achieve the same mass per square meter, showed that the change in weft yarn count and weft density influenced the fabric structure as a result of the crimp interchange. However, there was not a statistically significant difference among the three groups of fabrics when tested for air permeability.

\section{References}

[1] Milašius, V., Milašius, R., Kumpikaitè, E., Olšauskienè, A. Influence of Fabric Structure on Some Technological and End-use Properties, Fibres \& Textiles in Eastern Europe 11 (2) (2003) $48-51$

[2] Nosek, S. Dynamic Effects of Increase of Weaving Productivity, International Conference. The Textiles: Research and Technology Kaunas, Lithuania, 9 (2000) $32-42$.

[3] Hepworth, K. Theoretical Investigations of Beat-Up, Textile Research Journal 60 (1990) 554 - 556.
[4] Milašius, V., Milašius, R. Investigation of Unevennes of Some Fabric Cross-section Parameters, Fibres \& Textiles in Eastern Europe 10 (3) (2002) 42 - 49.

[5] Backer S. The relationship between the Structural Geometry of a Textile Fabric and its Physical Properties, Part IV: Interstice Geometry and Air Permeability, Textile Research Journal, 21 (10) (1951) 703 - 714.

[6] Zupin Ž, Hladnik A, Dimitrovski K. Prediction of one-layer woven fabrics air permeability using porosity parameters. Textile Research Journal, 82 (2) (2011) 117 - 128.

[7] Szosland J. Identification of Structure of Inter-Thread Channels in Models of Woven Fabrics, Fibres \& Textiles in Eastern Europe, 2 (1999) 41 - 45.

[8] Militký J, Havrdová M. Porosity and air permeability of clean room textiles, 3rd Int. Conf. IMCEMP Maribor (2000) 177- 183.

[9] Havrdová M. Prediction of woven fabric air permeability, 5th World Textile Conference AUTEX Portorož, Slovenia (2005)

[10] Gooijer H, Warmoeskerken, M, Wassink G. Flow resistance of textile materials, Part I: Monofilament Fabrics, Textile Research Journal, 73 (6) (2003) 437 - 443.

[11] Lu WM, at all. Fluid Flow Through basic Weaves of Monofilament Filter Cloth, Textile Research Journal, 66(5) (1996) $311-323$. 
Izvod

\section{UTICAJ PROMENE STRUKTURE VUNENIH TKANINA NA PROPUSTLJIVOST VAZDUHA}

Sonja Jordeva ${ }^{1}$, Elena Tomovska², Koleta Zafirova ${ }^{2}$

\footnotetext{
${ }^{1}$ Tehnološki fakultet, Univerzitet "Goce Delčev", Štip, Makedonija

${ }^{2}$ Tehnološko-metalurški fakultet, Univerzitet "Ćirilo i Metodije", Skopje, Makedonija
}

Tkanine su materijali sofisticirane strukture. Osnovni strukturni parametri, sirovinski sastav, podužna masa osnove i potke, upredenost pređa, gustina osnove i potke, utkanje osnove i potke i prepletaj tkanine, utiču na osnovna svojstva tkanina. Određeni osnovni parametri tkanine mogu se kontrolisati direktno ili tokom pripremnih procesa, ili tokom samog procesa tkanja. Međutim, postoje neki važni strukturni parametri za koje ne postoji direktna kvantitativna kontrola. Pošto su svi strukturni parametri tesno međusobno povezani, nedostatak direktnih rezultata kontrole ima za rezultat nesavršenu kontrolu strukture tkanine.

Bilo je potrebno istražiti kako male varijacije u konstrukciji polu-češljane vunene tkanine utiču na propustljivost vazduha i do koje mere se mogu kontrolisati u procesu projektovanja i tkanja tkanina.

Eksperiment je pokazao da su finoća pređe, gustina osnove i potke kao i utkanje osnove i potke veoma povezani i dovode do malih varijacija u fiksnom skupu. Statistička značajnost malih varijacija u grupama materijala je potvrđena analizom varijanse. Analiza je potvrdila da nije bilo razlike u masi, iako se svi drugi strukturni parametri razlikuju. Osim toga, post-hok Bonferroni test je pokazao da se strukturni parametri grupe tkanina, koje imaju praktično izbalansiranu strukturu, uvek razlikuju od onih iz grupe g2 i g3. Promene u tkanini koje su rađene sa istom osnovom, tako da se dobije ista masa po kvadratnom metru, su pokazale da promena finoće pređe i gustina potke utiču na strukturu tkanine kao rezultat promene utkanja. Međutim, nije bilo statistički značajnih razlika između tri grupe tkanina pri testiranju na propustljivost vazduha.
(STRUČNI RAD)

UDK 677.074.31:677.017.6

Ključne reči: propustljivost vazduha, strukturni parametri tkanina 